\title{
The System of Training Workers and Technicians for Kuzbass Mining Industry in the Late 20th - Early 21st Century: Challenges and Prospects
}

\author{
Vladislav Ovchinnikov ${ }^{1, *}$, Dmitry Kochergin ${ }^{1}$, Alexey Blinov ${ }^{2}$, and Timur Logunov ${ }^{2}$ \\ ${ }^{1}$ Kuzbass Regional Institute for Vocational Education Development, 650070 38A Tukhachevskogo \\ ul., Kemerovo, Russia \\ ${ }^{2}$ Kemerovo State University, 650000, 6, Krasnaya Ulitsa, Kemerovo, Russia
}

\begin{abstract}
The system of vocational education formed in the USSR was poorly adapted to the activity in market economy conditions, therefore, the 1990 s became the period of its adaptation to the market through a painful transformation. The paper analyzes the experience in target-oriented management of the of vocational education system of Kemerovo Region (Kuzbass) in the 2010s. New institutional mechanisms for training skilled workers and technicians for the region's coal industry are discussed. The authors conduct structural analysis of technical and vocational education in Kuzbass and identify major challenges and mechanisms for their overcoming, which have laid the foundations for further development of the education system.
\end{abstract}

\section{Introduction}

In general, by the end of the first decade of the 21 st century the system of vocational education had succeded in adapting to the market principles of functioning. At the same time, the side effects of non-systemic adaptation were becoming increasingly evident from year to year, forming the main challenge for its further activity and development.

In the recent history of Kemerovo Region, the 1990s was the most difficult period. Deregulation of economic activities in the region, spontaneous processes of privatization, significant equipment wear and insufficient funding for its renovation led to a sharp reduction in the main production capacities in all sectors of the Kuzbass economy. Market reforms aggravated problems in education sharply, replacing the objectives of stabilizing and developing the educational system by the dramatic objective task of its survival. For Kuzbass, breaking previously established ties between vocational education institutions and their basic enterprises became the most critical problem due to the narrow industry orientation formed in the Soviet period and the rigid territorial linkage of the vocational education system of the region to large industrial enterprises [1].

\footnotetext{
${ }^{*}$ Corresponding author: e-mail: rpcsib@,rambler.ru
} 


\section{Materials and Methods}

In the 1990-2000s, the region's imbalance in the level structure of vocational education deepened; the non-optimal territorial distribution of the of educational institution network increased in connection with the frequesnt duplication of training fields; standardized practices of interaction between educational institutions and business were not developed. Thus, the formed trend in the vocational education system development came into collision with long-range objectives of the neo-industrial economic development of Kuzbass.

To address this contradiction, the "Comprehensive Programme for the Development of the Vocational Education System of Kemerovo Region for 2014-2016" was developed; its implementation was supported in the framework of the Federal Targeted Programme for the Development of Education for 2011-2015. The programme was focused on the training of skilled workers for the coal mining industry of Kuzbass, carried out in three multidisciplinary ("polytechnic") and eight single-industry ("mining") institutions of vocational education. These institutions have become the sites for approbation of innovative mechanisms in the region's system of technical vocational education.

It should be noted that the consistent application of the systemic approach to optimizing the vocational education system in Kemerovo Region has made it possible to improve the efficiency of the territorial-industrial organization of secondary vocational education: by 2017 the number of vocational educational and training institutions (VET) had decreased to 57 (by 29 units compared to 2012) with the actual expansion of the list of secondary vocational educational programmes implemented in the region, as well as the retention of the number of students trained according to these programmes. In the framework of optimization processes of 2012-2013, many mining and polytechnic vocational institutions were joined by vocational and technical schools ("lyceums" in Russian) similar in their field of training, as a result of which 11 multi-level VETs were created. In the period that followed (2014-2017), the number of VETs training personnel for the coal mining industry of Kuzbass remained unchanged, and the number of students increased.

\section{Results and Discussion}

The introduction of the mechanisms of the regional industrial order for personnel training allowed optimizing the structure of staff training and emphasized the neo-industrial direction of the regional VET system: by 2016 the majority of students received a profession / specialty within the major field "Engineering, Technology and Industrial Sciences". Nearly 6000 people were trained in "Applied Geology, Mining, Oil and Gas Engineering and Geodesy", which is included in the above mentioned field of training, while the annual output of skilled workers and technicians for the coal industry was about 1600 people.

Expanding the practice of targeted training of qualified personnel was achieved through the creation of multifunctional centres of applied qualifications (MCAQ), institutions carrying out primary vocational training of workers and officers and their further training. During 5 years, 12 MCAQs were created in Kemerovo Region, including 4 MCAQs training personnel for the coal industry. Training workers for mining industry is a multilevel system, that is why the mining MCAQs implement a wide range of vocational training programmes (for example, MCAQ under Kemerovo Mining Technical College carries out 22 programmes), varying according to assigned skill categories. Another industrial feature of the MCAQs is training programmes in labour protection and industrial safety they offer, including those developed by request of coal mining companies. 
Table 1. Number of students trained according to secondary vocational programmes in the VET of Kemerovo Region in 2016.

\begin{tabular}{|l|c|c|c|c|}
\hline \multirow{2}{*}{ Fields of training } & \multicolumn{2}{|c|}{$\begin{array}{c}\text { Number of trainees in the } \\
\text { programmes for training } \\
\text { skilled workers }\end{array}$} & \multicolumn{2}{|c|}{$\begin{array}{c}\text { Number of trainees in the } \\
\text { programmes for training } \\
\text { middle level specialists }\end{array}$} \\
\cline { 2 - 5 } & $\begin{array}{c}\text { Number of } \\
\text { students, } \\
\text { persons }\end{array}$ & $\begin{array}{c}\text { The } \\
\text { proportion of } \\
\text { the total } \\
\text { number of } \\
\text { students, \% }\end{array}$ & $\begin{array}{c}\text { Number of } \\
\text { students, persons }\end{array}$ & $\begin{array}{c}\text { The } \\
\text { proportion of } \\
\text { the total } \\
\text { number of } \\
\text { students, \% }\end{array}$ \\
\hline $\begin{array}{l}\text { Engineering, Technologies } \\
\text { and Industrial Sciences }\end{array}$ & 9900 & 75.6 & 22390 & 54.5 \\
\hline Healthcare and Medicine & - & - & 3406 & 8.3 \\
\hline $\begin{array}{l}\text { Agriculture and } \\
\text { Agricultural Sciences }\end{array}$ & 859 & 6.6 & 1370 & 3.3 \\
\hline Social Science & 1188 & 9.1 & 6346 & 15.4 \\
\hline Education and Pedagogic & - & - & 3678 & 8.9 \\
\hline Humanities & 38 & 0.3 & 1543 & 3.8 \\
\hline Arts and Culture & 84 & 0.6 & 1766 & 4.3 \\
\hline Others & 1028 & 7.8 & 617 & 1.5 \\
\hline
\end{tabular}

Ensuring the compliance of VET graduates' qualifications with the requirements of industry specified in the training programme required changes in the internal VET environment, in the content of training, and creation of a regional mechanism for education quality management. The VET infrastructure was chosen as the priority for investment and targeted allocation of resources, with emphasis laid on acquisition of specialized training equipment that corresponds to state-of-art technologies of the coal industry: VETs were equipped with driving simulators of BelAZ dump trucks, FORWARD simulators of EKG-8 mining excavator, display boards "Gas Drainage of the Mine", "Technological Process in the Shaft Inset and on the Mine Surface", etc.

The elements of dual training were tested and introduced through creating VET structural units on the basis of enterprises of social partners. By 2017, all the VETs training personnel for the coal industry had structural divisions, where classes were conducted not only by VET teachers, but also by enterprise professionals. For example, Kemerovo Mining Technical School created an production-training centre on the basis of "Butovskaya Mine" LLC. The objectives of the Centre, in addition to providing conditions for the high-quality realization of the students' vocational training programmes, included creating conditions for conducting extra classes, extracurricular and research activities of students, studying new mining technologies, verification of practical skills and abilities of staff employed for underground mining operation.

One of the tools to increase the prestige of the workers occupations in the region was the promotion of the WorldSkills Russia (WSR) movement. The implementation of the regional WSR project was launched in 2012 when Kemerovo Region joined the movement a regional WSR Coordination Centre was established [2]. The dynamics of the WSR movement development in the region is well illustrated by the indicators of contestants and experts involved in competitions (Figure 1). In 2014, in order to make mining occupations more attractive among the Kuzbass youth regional contest in the "underground wireman" competence was held, which received the presentational status (i.e., this competence was not included in the national and international lists of WorldSkills competencies). Later on, this competency was presented at all the WSR championships in the region, its transfer it to the WSR core competencies is in progress. In 2016, Kemerovo Region started the organization of interregional training sites in the priority competencies for the Siberian regions under WSR standards. 


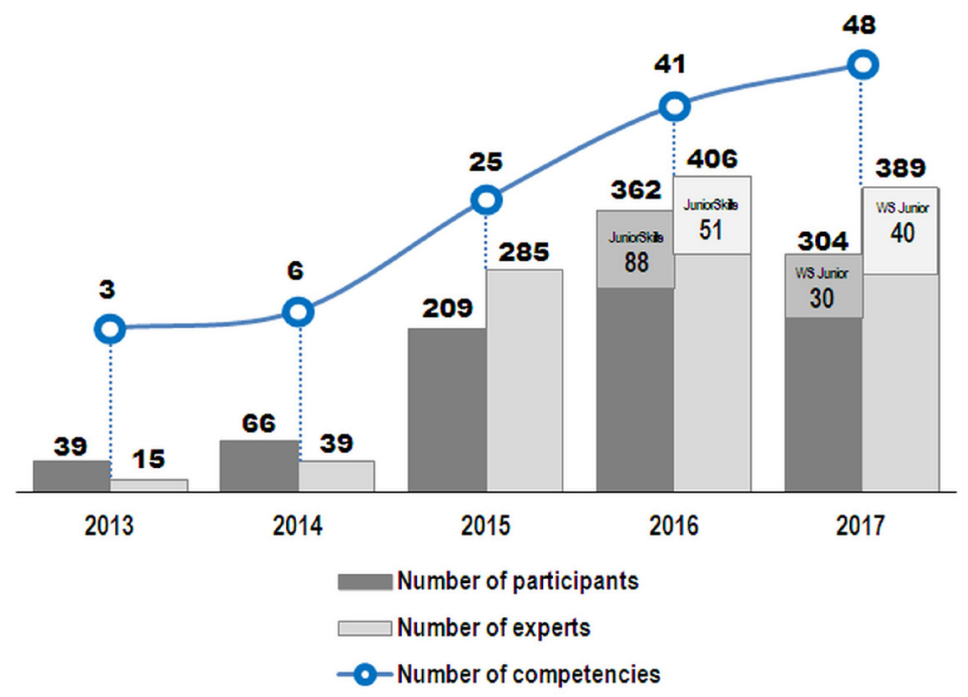

Fig. 1. Dynamics of the WorldSkills Russia movement indicators in Kemerovo Region in 2013-2017.

Thus, the implementation of the "Comprehensive Programme for the Development of the Education System of Kemerovo Region for 2014-2016" made it possible to accelerate the existing and create new mechanisms for overcoming the challenges within the shortest possible time, which formed the basis for further systemic changes in the vocational education to ensure compliance of the graduates' qualifications with the requirements of the industry. Despite the fact that the bulk of innovation and growth points in the VET system [3] created in the framework of the regional education programme have an institutional rather than a direct material nature, some positive structural changes can already be observed.

As noted above, the liberalization of education in the 1990s led to the formation of educational market intensifying competition between educational institutions of various types and levels [4-7]. As a result, the institutions of primary vocational education became the least competitive, however, the conditions of many technical and vocational schools were no better (Figure 2). This trend was further developing in the 2000s: by 2010 there were 350 students of higher education organizations and only about 250 of VET students for 10,000 people in Kuzbass.

It became possible to reverse the situation only in the mid 2010s thanks to, among other factors, the implementation of a comprehensive approach to managing the regional system of vocational education. The merger of primary and secondary vocational education institutions within the framework of secondary VETs after 2012 increased the attractiveness of vocational education for future skilled workers. So, in 2016, the number of students trained for skilled workers and middle level occupations in the region exceeded the number of students trained for Bachelor's and Master's degrees for the first time over the years.

At the same time, optimization has made it possible to increase the availability of programmes for training middle level specialists for the population of most areas in Kemerovo Region: the proportion of students enrolled in vocational middle level training programmes within the structure of training under the VET programmes in 2016 compared to 2012 increased by almost $9 \%$ (with an average national indicator being $5 \%$ ). This trend is also typical for the training of mining personnel: now, the majority of students $(83 \%)$ receive a middle level specialist's certificate, while mastering one or several workers occupations (for example, underground wireman, open-pit mining operator, mining equipment repairman). Such a change in the personnel training structure is one of the steps 
on the way to bringing together two regional markets: those of labour and educational services.

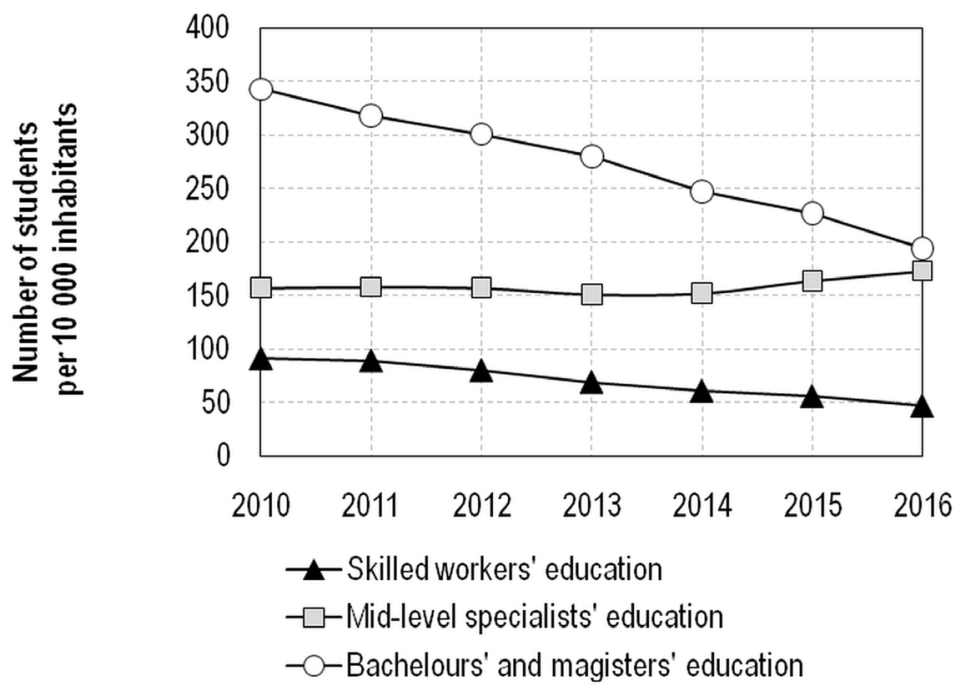

Fig. 2. The changes in the number of students in terms of education level per 10,000 population of Kemerovo region in 2010-2016.

The impact of "path dependence" effect, the dependence of the current state on the results of previous development in the sphere of social economic development is well known [8-9]. At the same time, under the conditions of liberal government policy, this effect is repeatedly reinforced: the leaders retain and strengthen their position by unregulated reallocation of national production factors. The considered case of modernization of the Kuzbass vocational education system in the 2010s shows that such negative trends can be reversed only by methods of management by objectives.

\section{Conclusion}

Further adjustment of the vocational education development in Kuzbass requires complex systematic changes. A central place among these processes should be held by the changes in training workers and technical personnel for the strategic sectors of the regional economy: the mining and chemical industries, metallurgy, machine building and metalworking. At the same time, other issues do not lose relevance, among them mid- and long-term planning of the region's economy demand for engineering and technical personnel, of developing advanced training mechanisms and further vocational education, and building partnerships between education and business in the field of personnel training. Undoubtedly, the dynamics of the social and economic development of Kemerovo Region directly depends on the successful solution of these tasks.

\section{References}

1. A. V. Blinov, A. N. Ermolaev, V. A. Ovchinnikov. The History of Primary and Secondary Mining Vocational Education in Kuzbass (the 18th - early 21st centuries) (SBU DPO "KRIRPO", Kemerovo, 2015) 
2. E. A. Pakhomova, V. A. Ovchinnikov, E. L. Rudneva, Vocational Education in Russia and Abroad., 18:2, 11-23 (2015).

3. V. A. Ovchinnikov, Vocational Education in Russia and Abroad. 11:3, 44-49 (2013)

4. D. C. North, Institutions, institutional change and economic performance (Cambridge University Press, New York, 1991)

5. M. A. Tyulenev, Economics and Innovation Management, 3, 80-86 (2017). DOI: 10.26730/2587-5574-2017-3-80-86

6. S. G. Kostyuk, A. A. Khoreshok, M. A. Tyulenev, Economics and Innovation Management, 3, 4-21 (2017). DOI: 10.26730/2587-5574-2017-3-4-21

7. L. V. Kusurgasheva, A. K. Muromtseva, Economics and Innovation Management, 1, 87-91 (2018). DOI: 10.26730/2587-5574-2018-1-87-91

8. A. Krechetov, E3S Web Conf., 15, 00001 (2017)

9. A. Krechetov, A. Khoreshok, V. Blumenstein, E3S Web Conf., 21, 00001 (2017) 